\title{
De entretenimiento en tiempos de streaming y pandemia. GOLUBOV, Nattie (ed.). (2019). ToFicciones: reflexiones críticas sobre televisión estadounidense. Ciudad de México: CISAN, UNAM.
}

\author{
MARIANA RIESTRA AHUMADA \\ Facultad de Filosofía y Letras ${ }^{1}$ \\ UNIVERSIDAD NAGionAL AUTÓNOMA DE MÉXico | México
}

工

da antología ToFicciones: Reflexiones críticas sobre televisión estadounidense (2019), editada por Nattie Golubov, investigadora del Centro de Investigaciones sobre América del Norte (CISAN), analiza algunas de las mercancías culturales más populares de los últimos veinte años. Los textos de la colección, escritos por autores y autoras de origen nacional e internacional, exploran la relación entre aquellos contenidos que consumimos tan fervientemente y el peso de los mismos en las esferas sociopolíticas que habitamos; esto en un contexto de aumento en la contratación de las plataformas de streaming que han revolucionado nuestra manera de ver televisión. El incremento de nuestras horas de conexión, así como la priorización del análisis cultural en el ciberespacio y en la vida real, han transformado también a los televidentes, quienes cada vez generan relaciones más complejas y tienen expectativas más altas de los productos culturales que consumen. Es verdad que nunca habíamos pasado tanto tiempo ante la pantalla y que la vida en el 2020 evidenció esto más que nunca -con una pandemia global como eje temático de nuestra cotidianidad, rodeados de injusticias sociales y de crisis climáticas-. El mundo como lo conocíamos cambió drásticamente: nuestras casas se transformaron en oficinas, escuelas, cines, bares y espacios de recreación. El último año pasamos más horas que nunca

${ }^{1}$ Estudiante de la Licenciatura en Letras y Literaturas Modernas (Letras Inglesas) 
viendo fijamente una pantalla y una honesta introspección nos haría notar que le dimos un nuevo uso al tiempo que antes destinábamos a transportarnos por la ciudad para producir y consumir, para laborar y, de ser posible, tomar un descanso en medio de lo que se siente como el fin del mundo. Fue así que las fiestas de cumpleaños, los exámenes profesionales y las reuniones con amigos encontraron un equivalente disímil en el ciberespacio, y que ir al cine o ver películas con tu mejor amiga se ha traducido en tener una Netflix party. Todo esto en nuestro afán por mantener la vida tan parecida a como la conocíamos en el mundo pre-pandemia.

Del mismo modo, la forma en que vemos series, películas e incluso las noticias ha cambiado radicalmente en los últimos tiempos y, con ello, el contenido vía streaming ha crecido un $10.5 \%$ en México anualmente (Aja, 2019). Plataformas como Netflix, Prime Video, Blim, $\mathrm{HBO}+$, entre otras, han transformado cómo consumimos contenido audiovisual, al permitirnos ver temporadas completas en cuestión de horas y desde prácticamente cualquier dispositivo. Esto ha dado pie a un nuevo foco de análisis para el estudio mediático que explora la manera en que consumimos contenido en internet y se pregunta qué tanto dicen de nosotros los productos culturales que nos rodean y que tan fervorosamente devoramos. Un buen ejemplo de esto es el libro que aquí se reseña.

En la introducción, titulada "Algunas coordenadas de lectura”, Golubov (2019) deja ver el enfoque desde los estudios culturales que caracteriza a la antología y que permite "entender mejor las narrativas que dramatizan los valores, ideales y formas de vida de la sociedad estadounidense" (13). Estos valores se han enmarañado en el imaginario colectivo de modo que las series y películas producidas en Estados Unidos determinan el modelo hegemónico de historias que consumimos. Asimismo,la colección se centra en el espectador moderno y el modo en que los productos culturales conversan entre ellos, lo que da lugar a una compleja red de contenidos que gratifica a quien ve y escucha atenta y vorazmente.

Golubov, quien ha analizado otras mercancías culturales en libros como Meridiano cero. Globalización, prácticas culturales y nuevas territorializaciones simbólicas (2016), El amor en tiempos neoliberales: apuntes críticos sobre la novela rosa contemporánea (2017), entre otros, colabora con investigadores e investigadoras de distintas entidades académicas y nacionalidades, lo que brinda un carácter amplio al análisis de los productos culturales arriba mencionados y deja entrever el alcance global de la televisión estadounidense. Además, la antología - focalizada en series dirigidas tanto 
a un público joven como a gente adulta - ofrece un estudio vasto sobre el contexto sociopolítico en el que nacen ciertos engranajes culturales, y la manera en que nutren y configuran a las poblaciones.

Más allá de esto, el libro abre a discusión el modo en que el público nutre y configura los productos culturales que le rodean gracias a la intermedialidad que un mundo en el que sobran plataformas para discutir, criticar o aclamar todo aquello que consumimos nos brinda. La nostalgia y el posfeminismo o la idealización del self-made man en series de época, lo que representa una amalgama entre el western y la ciencia ficción, la construcción de la latinidad, la sátira política y sus repercusiones en las encuestas y elecciones nacionales, entre otras aproximaciones, muestran la forma en que la televisión como fenómeno mediático atraviesa diferentes sectores demográficos. En ese sentido, artículos como "Del Viejo Oeste al nuevo Westworld: cuando el desierto se viste de silicón”, de Noemí Novell; “¿Qué tan lejos hemos llegado? Nostalgia y posfeminismo en Mad Men", de Holly Wilson Holladay; "La noción (emersoniana) del self-made man en el personaje Don Draper de Mad Men", de Rocío Saucedo Dimas; "Espacio de traducción sonora mexicoamericana: Dora la exploradora y los nuevos colonialismos mediáticos", de B. Guadalupe Caro Cocotle; e "Imitaciones políticas en Saturday Night Live durante las elecciones presidenciales de Estados Unidos de 2016", de Outi J. Hakola, se suman a las conversaciones sobre mercancías culturales alrededor de nosotros, a lo que leemos, escribimos, vemos o escuchamos en Twitter, Facebook, Reddit y Youtube.

El análisis de series de televisión y películas estadounidenses en años recientes con textos como The Age of Television: Experiences and Theories (2008), de Milly Buonanno; Complex TV: The Poetics of Contemporary Television Studies (2015), de Jason Mittel; y World Building: Transmedia, Fans, Industries (2017), editado por Marta Boni, reflejan la manera en que estos productos culturales hablan por y hacia audiencias que van más allá del contexto geográfico de Estados Unidos. Buonanno y Boni, por ejemplo, ambas académicas italianas, analizan fenómenos culturales ajenos a sus países de origen al igual que lo hacen los autores de Tivicciones; esto no sólo refuerza la idea del alcance - ahora magnificado por las plataformas de streaming - de la televisión estadounidense, sino que también resulta en la concepción de la cultura norteamericana como hegemónica y globalizante.

Tóficciones responde al creciente interés en el análisis de nuestras interacciones parasociales y en la vida real. La antología es accesible para el lector que está interesado tanto en 
la crítica literaria como en la cultura popular, ya que está repleta de referentes populares, diálogos e imágenes de las series para acompañar a los ensayos. Lo anterior saca a relucir el lado interactivo y conversacional de la academia que caracteriza al trabajo de Golubov en el ámbito de los estudios culturales. Asimismo, los artículos que completan la colección - de Fernando Ángel Moreno, Alan Hook, María de
Lourdes López Gutiérrez, Alberto N. García, y Graciela Martínez-Zalce Sánchez- ofrecen un acercamiento crítico que va más allá de las tendencias televisivas actuales o del crecimiento en nuestro consumo de contenidos audiovisuales: estos textos son pertinentes y vigentes al ofrecer un modelo para hablar del espacio lúdico y privado a partir de su alcance masivo y su reflejo en nuestros procesos identitarios.

\section{REFERENCIAS BIBLIOGRÁFICAS}

AJA, Antonio. (2019, 30 de octubre). "En ascenso, el consumo de contenido vía streaming” (en línea). El Economista, Opinión. Recuperado el 11 de julio de 2020 de https://www.eleconomista.com. mx/opinion/En-ascenso-el-consumo-de-contenido-via-streaming-20191030-0128.html

GOLubOV, Nattie (ed.). (2019). ToFicciones: Reflexiones críticas sobre televisión estadounidense. Ciudad de México: CISAN, UNAM. 